\title{
LIBERALISM AND DEMOCRACY IN THE PERSPECTIVE OF ISLAMIC EDUCATION
}

\author{
Marjuni', Yuspiani' ${ }^{2}$, Alwan Suban ${ }^{3}$ \\ 1,2,3Fakultas Tarbiyah dan Keguruan UIN Alauddin Makassar \\ 1,2,3Jalan H.M. Yasin Limpo No. 36 Samata-Gowa \\ Email: marjuni@uin-alauddin.ac.id ${ }^{1}$,yuspiani@uin-alauddin.ac.id², \\ alwan.suban@uinalauddin.ac.id ${ }^{3}$
}

\begin{abstract}
:
In the perspective of Islamic education, the concept of liberalism and democracy in education is about owning academic freedom, in which a lecturer can teach, and the students have the right to learn without limitation and mixing it with irrational thoughts. This paper aims to elaborate on the nature and the development of liberalism and democracy in Islamic higher education from different sources. The type of research used in this study was library research. The data were taken from various books and articles related to the topic then analyzed using content analysis. Based on the findings, the theory of the Islamic education philosophy about the concept of liberalism and democracy were so sustainable to provide possible solutions in education management, educational facilities, and infrastructure. Also, it could be a solution for educators to implement teaching methods or approaches that are more suitable for the learning process.
\end{abstract}

\begin{abstract}
Abstrak:
Dalam perspektif pendidikan Islam, konsep liberalisme dan demokrasi dalam pendidikan adalah tentang memiliki kebebasan akademik, dimana seorang dosen dapat mengajar, dan mahasiswa berhak untuk belajar tanpa batasan dan mencampurkannya dengan pemikiran-pemikiran yang irasional. Makalah ini bertujuan untuk mengelaborasi sifat dan perkembangan liberalisme dan demokrasi di perguruan tinggi Islam dari berbagai sumber. Jenis penelitian yang digunakan dalam penelitian ini adalah penelitian kepustakaan. Data diambil dari berbagai buku dan artikel yang berkaitan dengan topik tersebut kemudian dianalisis menggunakan analisis isi. Berdasarkan temuan tersebut, teori filosofi pendidikan Islam tentang konsep liberalisme dan demokrasi yang begitu lestari dapat memberikan solusi yang memungkinkan dalam pengelolaan pendidikan, sarana dan prasarana pendidikan. Selain itu, dapat menjadi solusi bagi pendidik untuk menerapkan metode atau pendekatan pengajaran yang lebih sesuai untuk proses pembelajaran.
\end{abstract}

\section{Keywords:}

Liberalism, Democracy, Education

How to Cite: Marjuni, Yuspiani, \& Suban, A. (2021). Liberalism and Democracy in the Perspective of Islamic Education. Lentera Pendidikan : Jurnal Ilmu Tarbiyah dan Keguruan, 24(1), 25-31. https://doi.org/10.24252/lp.2021v24n1i3.

\section{INTRODUCTION}

The concept of Islam and democracy has been considered significant in modern Islamic political education. To find an ideological foundation accepted by all circles in the Islamic world, thinkers from various circles of the Muslim community have begun to 
develop a new mission to reconcile the differences between various groups. The author believes that Islam and democracy strengthen each other, and the values of democracy can even be found in the Islamic teachings. Islamic education as a process of humanization requires the principles of freedom to optimally develop the students' capacity (Rahman, 2005). There are two dilemmas in Islamic education. The first one is related to phenomenological elements that argue whether or not Islam is compatible with democracy. The second one is related to the roots of democracy in the history of Islam (Sirry, 2002). In the context of living in a country, talking about democracy and justice means talking about the philosophical-constitutional foundation of our country, particularly implied in the fourth and the fifth principles of Pancasila: "Democracy guided by the inner wisdom in the unanimity arising out of deliberations among representatives," and "Social justice for the whole of the people of Indonesia." Although the term "democracy" is not literally mentioned in the Indonesian version of the 1945 Constitutional Preamble and its chapters as a result of the formulation created on August 18, 1945, the term "kerakyatan" in the fourth principle is translated into English as "democracy" because it refers to the system of democratic education (Maarif, 2014).

The current educational outputs are expected to fully produce graduates who are democrat and have good character and behavior. The Law of the Republic of Indonesia No. 20 of 2003 on the National Education system states explicitly that education is aimed at developing learners' potentials so that they become persons who are faithful and pious to one and only God; who possess noble character; who are knowledgeable, creative, physically and spiritually healthy, independent and responsible as citizens (Hosnan, 2018: 421-422). Education is conscious guidance from educators to learners regarding physical and spiritual development so that the learners have a better personality, which essentially leads to the forming of an ideal human being (Nata, 2015), as expected. The real concept of Islamic education can be searched in some verses in the Qur'an using the keywords "Al-Tarbiyah" and "Al-Ta'lim.

According to the interpretation of Indonesia's elites in education, the components of the national education curriculum, both the curriculum content and its management, still create an oppositional dualism. In this case, the formulation of the articles and verses in the curriculum content and the management of the national education system curriculum consist of the characteristics of liberal education ideology. The ideology of education in Indonesia is called the ideology of compromise liberalism and democracy (Aini, 2017). Therefore, this study analyzed two objectives: 1 ) to elaborate the nature and the development of liberalism and democracy, and 2) to determine the implication of the theory on Islamic education, especially in higher education.

\section{RESEARCH METHOD}

This research used a descriptive qualitative approach with library research, often referred to as a literature study. It is a series of activities related to collecting data from library sources, reading and taking notes, and processing research materials (Zed, 2008). On the other hand, according to Mahmud (2011: 31), library research is a type of 
research conducted through reading books, magazines, and other sources to collect data from various literature, either in libraries or other places.

Based on the explanation above, it could be understood that library research is an activity of reading books and taking notes of collected data, and processing/analyzing the collected data through several stages of literature study. Since this research was library research, the data is obtained from various literature, including books, articles, newspapers, personal documents, etc. Books covered the topic and background information of liberalism and democracy in the perspective of Islamic education, articles gave up-to-date and specific information, newspapers presented broad summaries of issues for a general audience, and other internet sources showed a wide variety of information. The collected data from various sources were analyzed using qualitative content analysis. The data were identified, processed, and analyzed to understand their meaning, significance, and relevance.

\section{RESULTS AND DISCUSSION}

\section{The Nature of Liberalism and Democracy in Education}

\section{The Concept of Liberalism}

The term "liberal" is derived from Latin "liber" which means free and not a slave or a condition in which someone is free from the ownership of others. The meaning of the word "free" has extended and become a class attitude of an educated community in western countries that opens the door to freedom of thought (The old Liberalism). By extending the meaning of "free" to become "freedom of thought," the word "liberal" has also been extended and has various meanings (Zarkaziy, 2009). Also, Subagja, as cited in Rahmat (2016), defines liberalism as an ideology that emphasizes individual or personal freedom, socio-political philosophy, and economics. It underlines or prioritizes individual freedom to make an agreement, production, consumption, exchange, and competition as well as the right to own all kinds of things personally.

Liberalism is an ideology that was initially emerged in Western countries (Fida, 2016). Liberalism originally came from ancient Greek, one of the essential elements of Western civilization. However, if traced back to the Middle Ages, the rise of liberalism was firstly triggered by the economic and political system, which were dominated by the feudal system. In the system, the king and aristocrats have special rights. At the same time, ordinary people are not allowed to freely exercise their rights, including in education, let alone the right to participate in the social mobilization that can lead them to be in the upper class.

The rise of liberalism began in 1215, when King John of England issued Magna Charta, a document that contained the rights and liberties granted by the king to subordinate aristocrats. The charter has automatically limited the power of King John himself and is considered a form of early liberalism. Early liberalism was originally characterized by resistance and restrictions on government power, which tended to be absolute (Zarkaziy, 2009). Liberal idealism is a product of Western modernization that has changed the old perspective considering that humans are controlled by something 
outside of themselves. The idea of modernism that stands out is enlightenment, selfawareness, and the shackles of tradition and dark times where the human mind was restricted for centuries. Classical liberalism produced many thinkers who aspire to bring up individuals to become the owner of their world autonomously and free themselves from the barriers that restrain their freedom to express themselves as human beings. Therefore, liberalism and individualism cannot be separated. Both form an idealogy and perspective, which was very important in the early period of modern ideas in the West (Bakar, 2014). Furthermore, according to Saada \& Gross (2016), the ideas of liberal Islam in the literature focus mainly on the implementation and interpretation of Islamic laws (Sharia) and how they are modified based on the dynamic life of the Muslim and nonMuslim community.

\section{The Concept of Democracy}

Etymologically, the word "democracy" is derived from the Greek language, which is originated from the word "demos" (people) and Kratos (rule/government). Based on history, the term "democracy" was firstly used around five centuries BC (Hakiki, 2016). It was used to respond to the negative experience of the monarchy and dictatorship in the city-states of Athens (Ancient Greece). At that time, democracy was implemented as a system in which all citizens formed a legislative function. It was possible because the citystate had approximately ten thousand and that women, children, and slaves had no political rights. At that time, there was no separation of powers. All officials were fully responsible to the People's Assembly, who was qualified to control various executive, judiciary, and legislature (Idris, 2019: 10).

The term "democracy" has three basic meanings: direct democracy, representative democracy, and liberal or constitutional democracy. Direct democracy is a form of government in which the power to make decisions is directly given to the citizens and exercised under majority rule. Representative democracy is a form of government in which people exercise the same rights on behalf of individuals and representatives. Meanwhile, liberal or constitutional democracy is a form of government. It is usually referred to as representative democracy. The power of the majority is exercised within a constitutional framework designed to ensure that all people obtain personal and collective rights, such as freedom of expression, speech, and religion (Idris, 2019: 12).

Based on the explanation above, the concept of conservatism, liberalism, and democracy in the review of Islamic education philosophy is the concept that can be an option in managing and developing all activities related to the development of the teaching and learning process. Therefore, teachers can compare the advantages and disadvantages of each concept to provide solutions in the teaching and learning process so as not to cause monotony.

\section{The Development of Liberalism and Democracy in Education The Development of Liberalism in Education}

For the supporters of liberal education, the most important thing in education is critical intelligence, which is formulated in effective problem solving, both at the personal 
and social levels (Syukran, 2019). In politics, liberalism is a political ideology that focuses on individuals who have rights in government, including equal rights to be respected, express and act, and be free from religious and ideological ties. In the social context, liberalism is defined as a social ethic that defends freedom (liberty) and equality in general (Zarkaziy, 2009).

In its development, liberalism generally has two main factions competing in using the term liberal. The first is liberal classic or early liberalism, which later became economic liberalism which emphasizes freedom in individual business, in the right to own property, in economic policy, and freedom of contract. This group supports equality before the law but not in the economy (economic inequality) because the distribution of wealth by the state does not guarantee prosperity. This group thinks that the competition in the free market gives more guarantees. The second is social liberalism. This faction emphasizes the more significant role of the state in defending individual rights (in a broad sense), often in the form of anti-discrimination laws. This group supports free education for the public (universal education) and the welfare of the people, including insurance for the unemployed, housing for the homeless, and health care for the sick people, which are all supported by the tax system. In other words, early liberalism emphasizes more on economic and political rights (Zarkaziy, 2009).

\section{The Development of Democracy in Education}

Islamic education and the concept of democracy in education are closely related. Therefore, one of the difficulties in filtering out the separate notions between democracy and educational philosophy suggested by John Dewey is that the two terms are completely interrelated.

In education, democracy is one of the human needs, including Muslims who need to realize harmony, peace, and a bright and guaranteed future. However, the implementation of democratic Islamic education can only be realized if all parties carry it out. Democracy in Islamic education to build humans' creativity, feeling, and intention, which is based on Islamic values, is always sensitive to changes that are taking place. In the ongoing era of reformation, people need to respond to things in various ways. At least every Muslim person can benefit from the critics conveyed to broaden his/her horizons, be democratic, tolerant, accept the truth, and not be exclusive. With the ongoing reformation era directed by critics, the Indonesian people have taken another step forward in fixing this nation towards improvement.

The determination to build and accomplish a more democratic Indonesia due to the reformation initiated by the younger generation must belong to everyone and be nationally supported. It is a solution and an alternative to anticipating the nation's decline since the last three decades and because education in Indonesia is expected to be democratic. The term "educational democracy" has been introduced by experts in the educational field. Still, the concept of democratic education has not yet been concrete, and therefore it has become a problem (Salim, 1999: 1). Different visions/concepts about education have been developed, and it is the right of each expert. 
Democratic education with educational values taught by the prophet of Muhammad is the education in Madinah, which was based on ideology, to educate, and to unite the Arabian Peninsula for the first time in history under the name of Islam. It was a new chapter in the political history of the Arabic peninsula. Islam was known to bring transformational changes in people's individual and social lives because of its ability to affect the quality of all aspects of life. According to Masamah (2016), Islamic education is expected to develop affective and psychomotor human beings capable of responding to internal and external challenges in implementing democratic education, efficiency, and critical thinking. As a result, Islamic education should be built based on paradigmoriented growth, renewal, creativity, intellectuality, abilities, and proficiency reasoning based on the sublime moral and personality.

Education and democracy are related in such a way as to make one almost indistinguishable from another, as it is hard to tell who has studied democracy and education will attest. There are three critical issues concerning education according to Dewey's work as cited in Idris (2019): (a) education is a fundamental cultural transformation tool which leads to a greater cultural reconstruction; (b) development is a fundamental educational goal which leads to the development of individuals and societies ultimately, and (c) building an educational system with the concept of experience is more important for the individual and subsequently for society.

Dewey's statement above explains that the philosophy of education and the concept of democracy are closely related so that they cannot be separated from one another. Education is considered a fundamental cultural transformation tool towards a cultural reconstruction and a fundamental educational goal towards developing individuals and societies where experience is more important for individuals and society.

Regarding the Islamic education philosophy theory, the concept of liberalism and democracy in education is very sustainable. The philosophy of Islamic education can provide solutions in managing anything related to education management, educational facilities, and infrastructure so that the program that has been proposed can be realized as planned. The concept of conservatism, liberalism, and democracy can be a solution for educators in implementing methods to transfer knowledge to choose the methods or approaches that are more suitable for the learning process.

\section{CONCLUSION}

The liberal concept is a product of Western modernization that has changed the old perspective considering that humans are controlled by something outside of themselves. The idea of modernism that stands out is enlightenment, self-awareness, and the shackles of tradition and dark times where the human mind was restricted for centuries. The theory of the Islamic education philosophy about the concept of liberalism and democracy is so sustainable that it can provide possible solutions in managing anything related to education management. The concept of liberalism and democracy can be a 
solution for educators in implementing methods to transfer knowledge to choose the methods or approaches that are more suitable for the learning process.

\section{REFERENCES}

Aini, R. (2017). Titik Temu Ideologi Pendidikan Islam Konservatif dan Liberal. UIN Sunan Kalijaga Yokyakarta, 2(2). https://doi.org/10.28918/jei.v2i2.1670.

Bakar, M. Y. A. (2014). Pengaruh Paham Liberalisme dan Neoliberalisme terhadap Pendidikan Islam di Indonesia. IAIN Sunan Ampel Surabaya.

Fida, I. A. (2016). Liberalisme dalam Pendidikan Islam di Perguruan Tinggi. Journal of Islamic Education, 1(1), 56-70. file:///C:/Users/PC/Downloads/Documents/garuda723510.pdf.

Hakiki, K. M. (2016). Islam dan Demokrasi: Pandangan Intelektual Muslim dan Penerapannya di Indonesia. Wawasan: Jurnal Ilmiah Agama Dan Sosial Budaya, 1(1), 1-17. http://dx.doi.org/10.15575/jw.v39i1.583.

Hosnan, M. (2018). Liberalisme Dalam Pendididikan Islam. Jurnal Pemikiran Dan Ilmu Keislaman, vol 1(2), hal.41. https://core.ac.uk/download/pdf/229473935.pdf.

Idris, S. (2019). Demokrasi dan Filsafat Pendidikan (Akar Filosofis dan Implikasinya dalam Pengembangan Filsafat Pendidikan) (Cet. I). Banda Aceh: Ar-Raniry Press.

Maarif, S. (2014). Mencari Autentisitas dalam Kegalauan (Cet. I). Jakarta: PSAP.

Mahmud. (2011). Metode Penelitian Pendidikan. Bandung: CV Pustaka Setia.

Masamah, U. (2016). Democracy and Education Islam. Ta'dib: Jurnal Pendidikan Islam, 20(2). https://doi.org/10.19109/td.v20i2.219.

Nata, A. (2015). Filsafat Pendidkan Islam. Jakarta: Gaya Media.

Rahman, M. (2005). Liberalisme dalam Pendidikan Akhlak. Jurnal Penididikan Islami, 14(1), 17-32. file:///C:/Users/PC/Downloads/Documents/jtptiain-gdl-jou-2005musthofara-1059-02_Liber-k.pdf.

Rahmat. (2016). Liberalisme dalam Pendidikan Islam (Implikasinya Terhadap Sistem Pembelajaran Agama Islam Di Sekolah). Nidhomul Haq, 1(2), 70-88. http://ejournal.ikhac.ac.id/index.php/nidhomulhaq/article/view/10.

Saada, N., \& Gross, Z. (2016). Islamic education and the challenge of democratic citizenship: a critical perspective. Discourse: Studies in the Cultural Politics of Education. https://doi.org/10.1080/01596306.2016.1191011.

Salim, A. M. (1999). Membangun Indonesia Baru di Era Reformasi dalam Perspektif Islam. Makassar: UIN Alauddin Makassar.

Sirry, M. A. (2002). Dilema Islam Dilema Demokrasi Pengalaman Baru Muslim Dalam Transisi Indonesia (Cet. I). Jakarta: PT. Gugus Pres.

Syukran. (2019). Liberalisme Pendidikan dan Implementasinya dalam Pendidikan Agama Islam (Analisis Pemikiran Carl R. Rogers). ITQAN, 10(2), 29-36. file:///C:/Users/PC/Downloads/541-Article Text-1350-2-10-20200107.pdf.

Zarkaziy, H. F. (2009). Liberalisasi Pemikiran Islam Gerakan Bersama Missionaris, $\begin{array}{llll}\text { Orientalis dan } & \text { Kolonialis. }\end{array}$ https://doi.org/10.21111/tsaqafah.v5i1.145.

Zed, M. (2008). Metode Penelitian Kepustakaan. Jakarta: Yayasan Obor Indonesia. 